\title{
Assessment of Communication and Teamwork Skills in Engineering Technol- ogy Programs
}

\section{Dr. Daniel K. Jones Ph.D., P.E. P.E., SUNYIT}

Dr. Jones is Associate Professor of Mechanical Engineering Technology and Chair of the Engineering Technology Department at SUNYIT in Utica, NY. He coordinates the ETAC/ABET accrediations processes. His technical interests include machine design, mechancial measurements, vibrations, instrumentation, and assistive technology for people with physical disabilities.

Dr. Mohammed Abdallah, SUNYIT 


\section{Assessment of Communication and Teamwork Skills in Engineering Technology Programs}

\section{Introduction}

Institutions of higher education have acknowledged that an effective teaching/learning process must involve assessing and evaluating what and how much students are learning. Assessment and evaluation leads to improvements in the educational experiences.

ETAC/ABET Criteria 3.B.e. and 3B.g. require that graduates demonstrate effective skills in teamwork and communication. ${ }^{1}$ Therefore, the goal of this project was to develop consistent and efficient methods for assessment of students' skills in these areas for different programs and instructors. Three separate rubrics have been developed to assess student outcomes in oral communication, written communication, and teamwork. A pilot study was conducted during spring, summer, and fall 2012 in upper-level courses in computer, electrical, and mechanical engineering technology programs.

\section{Development of the Rubrics and Assessment Processes}

The rubrics were designed based on similar rubrics for professionalism skills ${ }^{2}$ and capstone experience. ${ }^{3}$ When developing the rubrics, the goal was to limit each to one page with three to five concise performance indicators that captured the vital aspects of each student outcome. Each performance indicator was evaluated with performance levels on a scale of one to four. Each performance level contained a brief, thorough description of the expectations, clarifying the difference between the performance levels. The rubrics for oral communication, written communication, and teamwork are included in Appendices A, B, and C, respectively.

For the pilot study, the rubrics were used to assess student performance in upper-level courses in Computer Engineering Technology (CET), Electrical Engineering Technology (EET), and Mechanical Engineering Technology (MET). Since the goal of this outcomes-assessment was the evaluate students' performance near the end of their senior year, instructors provided scores in the three rubrics for each student in the capstone courses. A vital part of an assessment process is to identify areas for improvement, ${ }^{4}$ and so the results were evaluated to find areas where student performance was below standards.

For teamwork, students also evaluated their teammates confidentially using rubrics and written essays. Students were told in advance that their peer-assessment would remain confidential. They shared some perceptions of teamwork on paper that would otherwise not have been discussed in person within their groups. This helped to reveal the inner dynamics of the teams that may not have been apparent from outside observations, providing more complete information for instructors to evaluate individual students. In order to get all students to complete peerassessment, they were told that it was required in order to get a grade for the course. 


\section{Results}

Since students in CET and EET take the capstone course together, the rubric data were combined, and the results are summarized in Appendix D. Results for MET students are summarized in Appendix E. Each column in these tables represents a different performance indicator, and individual student scores are summarized at the bottom. The total number of students, as well as the percentage of students, scoring 4, 3, 2, and 1 was used to evaluate aggregate performance of the group. An initial benchmark was to have $70 \%$ of students scoring 3 or 4 , indicating that at least $70 \%$ of the students met or exceeded acceptable standards. An average score of less than $70 \%$ was used to identify a potential area for improvement.

\section{Discussion}

Since the intent of this project was to conduct a pilot study of the new rubrics, this section provides brief discussions of the results in order to show how they may be used to identify improvements. Additional data must be collected in the future in order to provide a more thorough analysis.

Observing the results for CET/EET students in Appendix D, consider the spring 2012 performance in oral communication category (a), the ability to speak with proper language and effective verbal communication. With only $66.7 \%$ of the students scoring 3 or 4 , the overall performance was below the $70 \%$ benchmark. Two of these students were very shy when speaking in front of the class, and the other two students had very few contributions toward the project, and so they could not speak with full confidence. Most of the students avoided presentations until the capstone course. Figure 1 shows improvements between spring and fall 2012; the number of scores of 2 and 3 decreased, and scores of 4 increased. The students with more experience giving presentations were much better speakers.

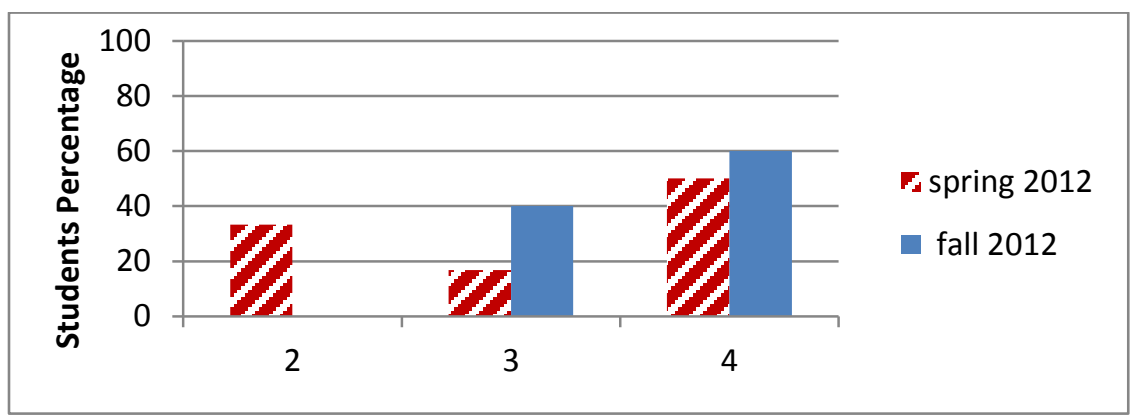

Figure 1. Percentage of CET/EET students scoring 2, 3, and 4 in performance indicator for oral communication category (a).

Consider the performance of CET/EET students in teamwork category (b), the ability to fulfill team roles and responsibilities. During spring 2012, only $66.7 \%$ scored 3 or 4, indicating another area below the benchmark. Again, a third of the class scored 2 out of 4 . As the capstone projects evolve, students distribute the responsibilities among themselves. If someone does not fulfill a task toward the end of the semester, another team member completes the task to save the group grades. This fact was revealed in their individual peer-assessment reports, and it would have been difficult to detect this problem without the peer-assessment. We also noticed that each of 
the students with low scores were members of a large group. In fall 2012, the team size was limited to three students, and this lead to an improvement with $90 \%$ of the students scoring 3 or 4.

Observing the results for MET students in Appendix E, the 70\% benchmark was achieved for all performance indicators in spring 2012. However, the scores in summer and spring 2012 declined substantially, with only half of the indicators meeting the benchmark. At the end of summer, the poor performance was initially attributed to the fact that the summer term was short (8 weeks instead of 15), with fewer weekly meetings, more independent projects, most students working full-time, and time off for vacation.

Although these issues may be valid, the poor performance continued in fall 2012. The most successful students who graduate in four years typically take the capstone course during spring of their senior year, and students who take longer to graduate typically take the course during the summer or fall. Perhaps these students do not perform well, especially when working on teams of similar peers. To see how this trend relates to a specific performance measure, Figure 2 shows the trend for teamwork performance category (a), the ability to communicate within the team. Between spring and the subsequent fall, the number of students scoring 3 or 4 dropped from $100 \%$ to $77.8 \%$. Although this is still above the $70 \%$ benchmark, there is a clear drop in effective communication among team members. Ongoing assessment will continue in spring 2013 to see if the trend continues.

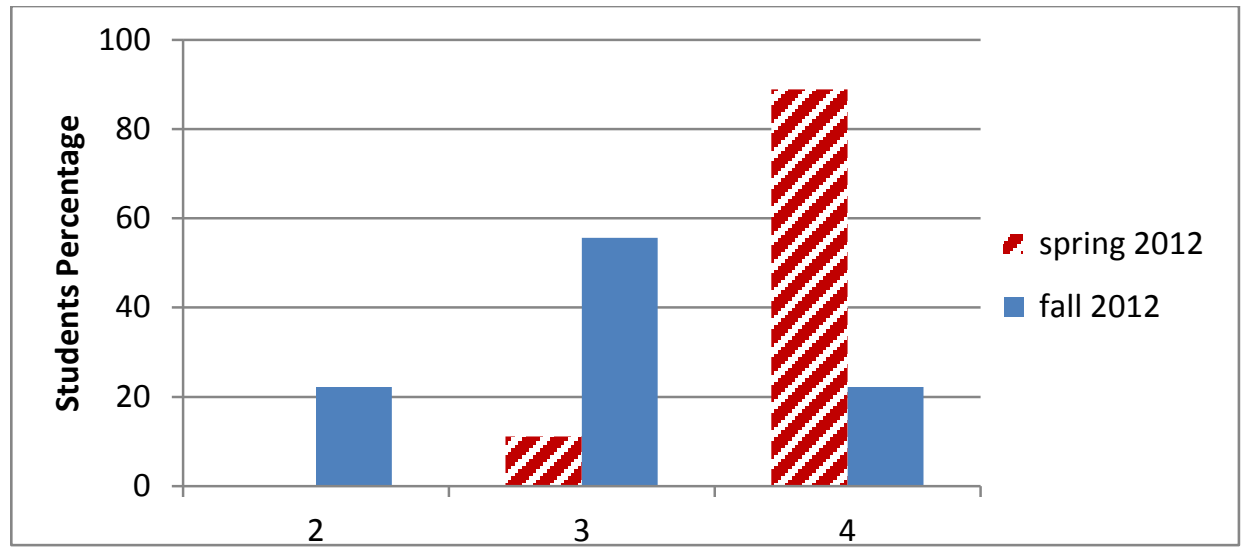

Figure 2. Percentage of MET students scoring 2, 3, and 4 in performance indicator for teamwork category (a).

\section{Recommendations for Improvement}

It is important to realize the limitations of the rubrics and assessment processes outlined in this paper. Student's performance in teamwork and communication skills was evaluated by the instructors of students in their courses. Teamwork was also evaluated by fellow students within each team. One of the disadvantages to this approach is that it has been limited to selfassessment. Ideally, assessment should be conducted by an external evaluator such as an instructor who teaches speech or writing courses, a practicing engineer, or a member of the advisory board. Also, additional assessment techniques are recommended for each student outcome; rubrics alone are not sufficient. 
In order to understand expectations, students were given copies of the rubrics at the beginning of the semester, and the rubrics were used throughout the semester to reinforce the expectations. However, since assessment was done at the end of the semester, students did not have the opportunity to see their scores. Giving students a mid-semester evaluation would provide feedback, and the data could be used to track improvement throughout the semester.

The instructors had limited interaction with teams and individuals, and so the peer-assessment of teamwork provided valuable information, particularly when determining the individual contributions of each student to the overall effort. Likewise, the mid-semester and final oral presentations provided additional insight. However, the peer-assessments were student biased, and so instructor's evaluation involved some speculation. An additional teamwork assessment is recommended in other classes. Also, a single final report was submitted by each group, and so it was not possible to assess the individual performance for written communication. A more valid approach would be to assess writing skills for individual laboratory reports from other classes during the senior year. The new rubrics would be much more effective if used in a variety of courses.

\section{Conclusion}

A pilot study has been conducted for three new rubrics to assess communication and teamwork skills. Results have been summarized and evaluated, and potential improvements have been identified. Pilot data and feedback from instructors indicate that the rubrics were very useful. When instructors started using the rubrics, it took some initial time upfront to understand the distinctions between the various performance levels. After some experience, the rubrics provided a very rapid and efficient method of assessment.

\section{Acknowledgement}

The authors would like to thank their colleague, (insert name after review), for valuable assistance in developing the rubrics.

\section{Bibliography}

1. Criteria for Accrediting Engineering Technology Programs, Effective for Reviews During the 2013-2014 Accreditation Cycle, Engineering Technology Accreditation Commission of ABET, www.abet.org, ABET Inc., October 2012.

2. Jones DK, Baran SJ, and Hsie A, "A New Course to Assess Professionalism Skills Required by ABET," 2011 Conference on Innovations in Engineering and Technology Education, ASEE St. Lawrence Section, Albany, NY, March 2011.

3. Jones DK and Tadros AK, "Successful Use of Rubrics to Assess Student Performance in Capstone Projects," 2010 ASEE Annual Conference, Louisville, Kentucky, June 2010.

4. Lingard R, "A Process for the Direct Assessment of Program Learning Outcomes Based on the Principles and Practices of Software Engineering," 2007 ASEE Annual Conference, June 2007. 


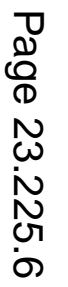




\section{Appendix A. Rubric on Oral Communication}

Course:

Date:

Evaluator:

Student Evaluated:

Project Evaluated:

Performance Indicator

\begin{tabular}{|c|c|c|c|c|c|}
\hline $\begin{array}{l}\text { Student } \\
\text { demonstrated } \\
\text { the ability to: }\end{array}$ & $\begin{array}{l}1 \text { - Not } \\
\text { acceptable }\end{array}$ & $\begin{array}{l}2 \text { - Below } \\
\text { standards }\end{array}$ & $\begin{array}{l}3 \text { - Meets } \\
\text { standards }\end{array}$ & 4 - Exemplary & Score \\
\hline $\begin{array}{l}\text { a. Speak with } \\
\text { proper } \\
\text { language and } \\
\text { effective } \\
\text { verbal } \\
\text { communicati } \\
\text { on } \\
\end{array}$ & $\begin{array}{l}\text { Serious } \\
\text { problems with } \\
\text { focus and/or } \\
\text { clarity, } \\
\text { Low volume, } \\
\text { poor eye contact }\end{array}$ & $\begin{array}{l}\text { Presents } \\
\text { misconstructions, } \\
\text { disjointed, limited } \\
\text { eye contact }\end{array}$ & $\begin{array}{l}\text { Persuasive, clear } \\
\text { communication, } \\
\text { good eye contact }\end{array}$ & $\begin{array}{l}\text { Succinct, clear, } \\
\text { coherent, } \\
\text { maintains } \\
\text { consistent eye } \\
\text { content with } \\
\text { audience }\end{array}$ & \\
\hline $\begin{array}{l}\text { b. Organize the } \\
\text { content in a } \\
\text { logical } \\
\text { fashion }\end{array}$ & $\begin{array}{l}\text { Sloppy, unclear, } \\
\text { illogical } \\
\text { sequence of } \\
\text { information, } \\
\text { vague, presents } \\
\text { data without } \\
\text { explanation }\end{array}$ & $\begin{array}{l}\text { Awkward, difficult } \\
\text { to follow, } \\
\text { disorganized, } \\
\text { analysis is flawed } \\
\text { or inappropriate }\end{array}$ & $\begin{array}{l}\text { Well organized } \\
\text { and developed, } \\
\text { logical sequence } \\
\text { of information }\end{array}$ & $\begin{array}{l}\text { Highly } \\
\text { professional } \\
\text { presentation, } \\
\text { fully justifies } \\
\text { findings }\end{array}$ & \\
\hline $\begin{array}{l}\text { c. Provide } \\
\text { graphical } \\
\text { illustrations }\end{array}$ & $\begin{array}{l}\text { Lack of } \\
\text { adequate } \\
\text { illustrations, } \\
\text { irrelevant to the } \\
\text { topic }\end{array}$ & $\begin{array}{l}\text { Limited use of } \\
\text { illustrations, shows } \\
\text { some of the } \\
\text { concepts, but not } \\
\text { all }\end{array}$ & $\begin{array}{l}\text { Adequately } \\
\text { shows important } \\
\text { concepts, clearly } \\
\text { relevant, multiple } \\
\text { sources }\end{array}$ & $\begin{array}{l}\text { Use of } \\
\text { multimedia, } \\
\text { maximizes the } \\
\text { use of time, } \\
\text { variety of } \\
\text { illustrations } \\
\text { from a range of } \\
\text { sources }\end{array}$ & \\
\hline $\begin{array}{l}\text { d. Identify and } \\
\text { explain the } \\
\text { topic with } \\
\text { technical } \\
\text { depth }\end{array}$ & $\begin{array}{l}\text { Fails to } \\
\text { persuade, little } \\
\text { use of college } \\
\text { skills, proposed } \\
\text { goals are not } \\
\text { addressed }\end{array}$ & $\begin{array}{l}\text { Focus on work of } \\
\text { others, } \\
\text { inappropriate or } \\
\text { insufficient details } \\
\text { to support ideas }\end{array}$ & $\begin{array}{l}\text { Use of skills } \\
\text { from college } \\
\text { courses, } \\
\text { proposed goals } \\
\text { are complete }\end{array}$ & $\begin{array}{l}\text { Advanced } \\
\text { insight, } \\
\text { exceeds goals } \\
\text { of project, } \\
\text { focus on new } \\
\text { understandings }\end{array}$ & \\
\hline
\end{tabular}




\section{Appendix B. Rubric on Written Communication}

Course:

Student Evaluated:
Date:

Evaluator:

Project Evaluated:

Performance Indicator

\begin{tabular}{|c|c|c|c|c|c|}
\hline $\begin{array}{l}\text { Student } \\
\text { demonstrated } \\
\text { the ability to: }\end{array}$ & $\begin{array}{c}1 \text { - Not } \\
\text { acceptable }\end{array}$ & $\begin{array}{l}2 \text { - Below } \\
\text { standards }\end{array}$ & $\begin{array}{l}\text { 3-Meets } \\
\text { standards }\end{array}$ & 4 - Exemplary & Score \\
\hline $\begin{array}{l}\text { a. Organize } \\
\text { the content } \\
\text { with } \\
\text { appropriate } \\
\text { methodology }\end{array}$ & $\begin{array}{l}\text { Incomprehensible, } \\
\text { extremely vague, } \\
\text { excludes data or } \\
\text { presents findings } \\
\text { without } \\
\text { explanation }\end{array}$ & $\begin{array}{l}\text { Analysis is flawed } \\
\text { or inappropriate, } \\
\text { unclear, vague, } \\
\text { does not question } \\
\text { findings }\end{array}$ & $\begin{array}{l}\text { Clearly } \\
\text { evaluates } \\
\text { findings, } \\
\text { explains } \\
\text { procedure, } \\
\text { minor errors or } \\
\text { omissions }\end{array}$ & $\begin{array}{l}\text { Documentation } \\
\text { is complete, } \\
\text { clear, and } \\
\text { appropriate, } \\
\text { fully justifies } \\
\text { findings }\end{array}$ & \\
\hline $\begin{array}{l}\text { b.Identify and } \\
\text { explain the } \\
\text { topic with } \\
\text { appropriate } \\
\text { technical } \\
\text { depth }\end{array}$ & $\begin{array}{l}\text { Little use of } \\
\text { college-level skills, } \\
\text { unclear proposal, } \\
\text { proposed goals are } \\
\text { not addressed }\end{array}$ & $\begin{array}{l}\text { Lack of technical } \\
\text { content, proposed } \\
\text { goals are not fully } \\
\text { complete, focus on } \\
\text { work of others }\end{array}$ & $\begin{array}{l}\text { Use of skills } \\
\text { from college } \\
\text { courses, } \\
\text { proposed goals } \\
\text { are complete }\end{array}$ & $\begin{array}{l}\text { Advanced } \\
\text { insight, exceeds } \\
\text { goals of project, } \\
\text { focus on new } \\
\text { understanding }\end{array}$ & \\
\hline $\begin{array}{l}\text { c. Write with } \\
\text { proper } \\
\text { language and } \\
\text { correct } \\
\text { grammar }\end{array}$ & $\begin{array}{l}\text { Grammar errors, } \\
\text { misspelling, } \\
\text { misrepresents } \\
\text { information, brief }\end{array}$ & $\begin{array}{l}\text { Misconstructions, } \\
\text { unclear, difficult } \\
\text { to follow, some } \\
\text { errors in } \\
\text { formatting, } \\
\text { punctuation, or } \\
\text { syntax }\end{array}$ & $\begin{array}{l}\text { Grammatically } \\
\text { correct, } \\
\text { thorough } \\
\text { explanations, } \\
\text { straightforward }\end{array}$ & $\begin{array}{l}\text { Excellent blend } \\
\text { of explanations } \\
\text { and } \\
\text { illustrations, } \\
\text { full detail, no } \\
\text { grammar errors }\end{array}$ & \\
\hline $\begin{array}{l}\text { d.Provide } \\
\text { graphical } \\
\text { illustrations }\end{array}$ & $\begin{array}{l}\text { Lack of adequate } \\
\text { illustrations, } \\
\text { irrelevant to topic, } \\
\text { not labeled }\end{array}$ & $\begin{array}{l}\text { Limited use of } \\
\text { illustrations, } \\
\text { shows some of the } \\
\text { concepts, but not } \\
\text { all, incomplete } \\
\text { labels }\end{array}$ & $\begin{array}{l}\text { Adequately } \\
\text { shows } \\
\text { important } \\
\text { concepts, most } \\
\text { are labeled to } \\
\text { indicate } \\
\text { relevance }\end{array}$ & $\begin{array}{l}\text { Extensive use } \\
\text { of a variety of } \\
\text { illustrations } \\
\text { from a range of } \\
\text { sources, } \\
\text { completely } \\
\text { labeled }\end{array}$ & \\
\hline $\begin{array}{l}\text { e. Utilize } \\
\text { quality and } \\
\text { quantity of } \\
\text { external } \\
\text { references } \\
\text { and resources }\end{array}$ & $\begin{array}{l}\text { Does not collect } \\
\text { external } \\
\text { information, } \\
\text { irrelevant sources, } \\
\text { plagiarism, } \\
\text { dishonesty }\end{array}$ & $\begin{array}{l}\text { Inadequate } \\
\text { background } \\
\text { research, limited } \\
\text { use of external } \\
\text { sources, lacks } \\
\text { variety of } \\
\text { references }\end{array}$ & $\begin{array}{l}\text { Identifies and } \\
\text { presents useful } \\
\text { sources, } \\
\text { correctly } \\
\text { formatted and } \\
\text { referenced }\end{array}$ & $\begin{array}{l}\text { Collects } \\
\text { extensive } \\
\text { relevant } \\
\text { information } \\
\text { from a wide } \\
\text { range of } \\
\text { sources, } \\
\text { validates }\end{array}$ & \\
\hline
\end{tabular}




\section{Appendix C. Rubric on Teamwork}

Course:

Student Evaluated:
Date:

Project Evaluated:
Evaluator:

Team Number:

\section{Performance Indicator}

\begin{tabular}{|c|c|c|c|c|c|}
\hline $\begin{array}{l}\text { Student } \\
\text { demonstrated } \\
\text { the ability to: }\end{array}$ & $\begin{array}{l}1 \text { - Not } \\
\text { acceptable }\end{array}$ & $\begin{array}{l}2 \text { - Below } \\
\text { standards }\end{array}$ & $\begin{array}{l}\text { 3-Meets } \\
\text { standards }\end{array}$ & 4 - Exemplary & Score \\
\hline $\begin{array}{l}\text { a. communicate } \\
\text { within the } \\
\text { team }\end{array}$ & $\begin{array}{l}\text { Does not } \\
\text { communicate } \\
\text { or share } \\
\text { knowledge, } \\
\text { argues without } \\
\text { resolution }\end{array}$ & $\begin{array}{l}\text { Communicates } \\
\text { poorly, shares } \\
\text { little knowledge }\end{array}$ & $\begin{array}{l}\text { Communicates } \\
\text { clearly, shares } \\
\text { basic knowledge }\end{array}$ & $\begin{array}{l}\text { Communicates } \\
\text { highly } \\
\text { effectively, } \\
\text { shares all } \\
\text { important and } \\
\text { relevant } \\
\text { knowledge }\end{array}$ & \\
\hline $\begin{array}{l}\text { b. fulfill team } \\
\text { roles and } \\
\text { responsibiliti } \\
\text { es }\end{array}$ & $\begin{array}{l}\text { Irresponsible, } \\
\text { uncooperative, } \\
\text { always relies } \\
\text { on others to } \\
\text { complete tasks }\end{array}$ & $\begin{array}{l}\text { Little } \\
\text { responsibility, } \\
\text { insufficient } \\
\text { contribution, } \\
\text { often needs } \\
\text { reminded, } \\
\text { overly relies on } \\
\text { others } \\
\end{array}$ & $\begin{array}{l}\text { Very responsible, } \\
\text { cooperative, } \\
\text { rarely needs } \\
\text { reminded, self- } \\
\text { motivated, works } \\
\text { toward group } \\
\text { goals }\end{array}$ & $\begin{array}{l}\text { Highly } \\
\text { responsible, takes } \\
\text { initiative, } \\
\text { exhibits } \\
\text { leadership, } \\
\text { coordinates } \\
\text { efforts, } \\
\text { encourages others }\end{array}$ & \\
\hline $\begin{array}{l}\text { c. listen to } \\
\text { teammates }\end{array}$ & $\begin{array}{l}\text { Always talks, } \\
\text { does not allow } \\
\text { others to speak, } \\
\text { does not listen } \\
\text { to others }\end{array}$ & $\begin{array}{l}\text { Usually doing } \\
\text { most of the } \\
\text { talking, rarely } \\
\text { allows others to } \\
\text { speak, does not } \\
\text { authentically } \\
\text { listen to others }\end{array}$ & $\begin{array}{l}\text { Listens to others, } \\
\text { but sometimes } \\
\text { talks too much }\end{array}$ & $\begin{array}{l}\text { Always listens to } \\
\text { others, values the } \\
\text { ideas of others, } \\
\text { asks questions to } \\
\text { prompt ideas }\end{array}$ & \\
\hline
\end{tabular}

Note: Students may be asked to evaluate their teammates. 


\section{Appendix D. Summary of Results for Computer and Electrical Engineering Technology}

\begin{tabular}{|c|c|c|c|c|c|c|c|c|c|c|c|c|}
\hline \multicolumn{10}{|c|}{ ETC 445, Capstone Experience } & \multicolumn{3}{|c|}{ instructor's evaluation } \\
\hline spring 2012 (12) & oral a & oral b & oral c & oral d & writ a & writ b & writ c & writ d & writ e & team a & team b & team c \\
\hline S1 & 4 & 3 & 3 & 4 & 4 & 3 & 4 & 3 & 3 & 3 & 2 & 3 \\
\hline S2 & 4 & 3 & 3 & 4 & 4 & 3 & 4 & 3 & 3 & 4 & 4 & 4 \\
\hline S3 & 3 & 3 & 3 & 3 & 4 & 3 & 4 & 3 & 3 & 3 & 2 & 3 \\
\hline S4 & 4 & 4 & 3 & 4 & 4 & 3 & 4 & 3 & 3 & 4 & 4 & 4 \\
\hline S5 & 4 & 4 & 3 & 3 & 4 & 3 & 4 & 3 & 4 & 4 & 4 & 4 \\
\hline S6 & 3 & 3 & 2 & 2 & 4 & 3 & 4 & 3 & 3 & 4 & 2 & 2 \\
\hline S7 & 2 & 3 & 2 & 3 & 4 & 3 & 4 & 3 & 4 & 4 & 4 & 4 \\
\hline S8 & 2 & 2 & 3 & 2 & 3 & 2 & 3 & 3 & 3 & 2 & 2 & 2 \\
\hline S9 & 2 & 3 & 3 & 3 & 3 & 2 & 3 & 3 & 3 & 4 & 4 & 4 \\
\hline S10 & 4 & 3 & 3 & 3 & 4 & 3 & 4 & 3 & 3 & 4 & 3 & 4 \\
\hline S11 & 2 & 2 & 3 & 3 & 4 & 3 & 4 & 3 & 3 & 3 & 3 & 2 \\
\hline $\mathrm{S} 12$ & 4 & 4 & 3 & 4 & 4 & 3 & 4 & 3 & 3 & 4 & 3 & 4 \\
\hline scores of 4 & 6 & 3 & 0 & 4 & 10 & 0 & 10 & 0 & 2 & 8 & 5 & 7 \\
\hline scores of 3 & 2 & 7 & 10 & 6 & 2 & 10 & 2 & 12 & 10 & 3 & 3 & 2 \\
\hline scores of 2 & 4 & 2 & 2 & 2 & 0 & 2 & 0 & 0 & 0 & 1 & 4 & 3 \\
\hline$\%$ scoring 4 & 50.0 & 25.0 & 0.0 & 33.3 & 83.3 & 0.0 & 83.3 & 0.0 & 16.7 & 66.7 & 41.7 & 58.3 \\
\hline \% scoring 3 & 16.7 & 58.3 & 83.3 & 50.0 & 16.7 & 83.3 & 16.7 & 100.0 & 83.3 & 25.0 & 25.0 & 16.7 \\
\hline$\%$ scoring 2 & 33.3 & 16.7 & 16.7 & 16.7 & 0.0 & 16.7 & 0.0 & 0.0 & 0.0 & 8.3 & 33.3 & 25.0 \\
\hline \multicolumn{13}{|c|}{ CET/ETC 423, Capstone Experience } \\
\hline fall $2012(10)$ & oral a & oral b & oral c & oral d & writ a & writ b & writ c & writ d & writ e & team a & team b & team c \\
\hline S1 & 4 & 4 & 3 & 4 & 4 & 4 & 4 & 4 & 3 & 4 & 4 & 4 \\
\hline S2 & 3 & 4 & 3 & 3 & 4 & 4 & 4 & 4 & 3 & 4 & 4 & 4 \\
\hline S3 & 4 & 4 & 3 & 4 & 3 & 4 & 4 & 3 & 3 & 4 & 4 & 4 \\
\hline S4 & 3 & 4 & 3 & 3 & 3 & 4 & 4 & 3 & 3 & 4 & 3 & 4 \\
\hline S5 & 3 & 4 & 3 & 3 & 3 & 4 & 4 & 3 & 3 & 4 & 3 & 4 \\
\hline S6 & 4 & 4 & 3 & 4 & 4 & 4 & 4 & 4 & 4 & 4 & 4 & 4 \\
\hline S7 & 3 & 4 & 3 & 4 & 4 & 4 & 4 & 4 & 4 & 4 & 2 & 4 \\
\hline S8 & 4 & 4 & 3 & 4 & 4 & 4 & 4 & 4 & 3 & 4 & 4 & 4 \\
\hline S9 & 4 & 4 & 3 & 4 & 4 & 4 & 4 & 4 & 3 & 4 & 4 & 4 \\
\hline S10 & 4 & 4 & 3 & 4 & 4 & 4 & 4 & 4 & 3 & 4 & 4 & 4 \\
\hline scores of 4 & 6 & 10 & 0 & 7 & 7 & 10 & 10 & 7 & 2 & 10 & 7 & 10 \\
\hline scores of 3 & 4 & 0 & 10 & 3 & 3 & 0 & 0 & 3 & 8 & 0 & 2 & 0 \\
\hline scores of 2 & 0 & 0 & 0 & 0 & 0 & 0 & 0 & 0 & 0 & 0 & 1 & 0 \\
\hline$\%$ scoring 4 & 60.0 & 100.0 & 0.0 & 70.0 & 70.0 & 100.0 & 100.0 & 70.0 & 20.0 & 100.0 & 70.0 & 100.0 \\
\hline$\%$ scoring 3 & 40.0 & 0.0 & 100.0 & 30.0 & 30.0 & 0.0 & 0.0 & 30.0 & 80.0 & 0.0 & 20.0 & 0.0 \\
\hline \% scoring 2 & 0.0 & 0.0 & 0.0 & 0.0 & 0.0 & 0.0 & 0.0 & 0.0 & 0.0 & 0.0 & 10.0 & 0.0 \\
\hline
\end{tabular}




\section{Appendix E. Summary of Results for Mechanical Engineering Technology}

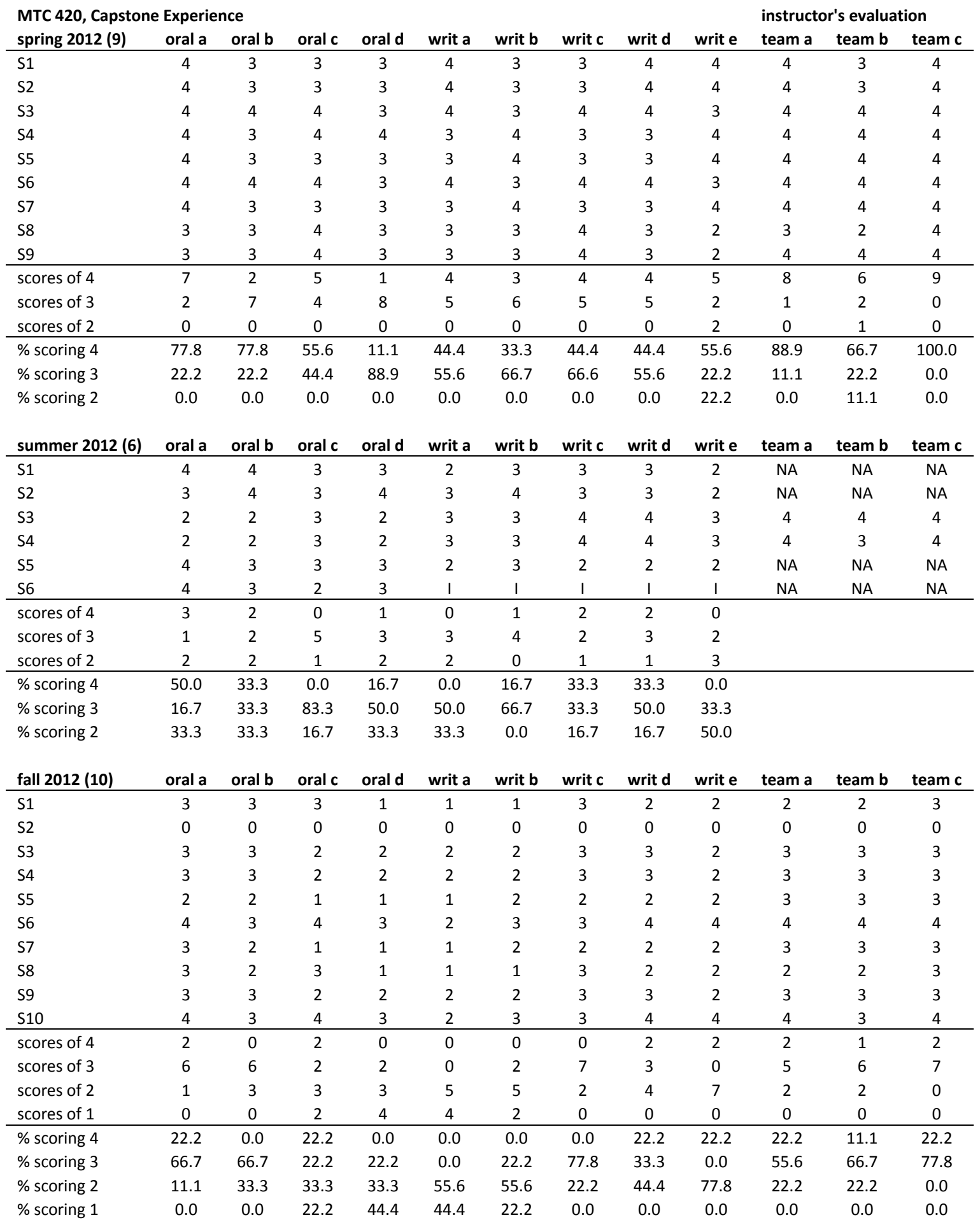

